\title{
Evaluation of antioxidants on oxidative stability and fatty acid profile of poultry offal oil used in the pet food industry
}

\section{Avaliação de antioxidantes sobre a estabilidade oxidativa e perfil de ácidos graxos do óleo de vísceras de aves utilizado na indústria pet food}

\author{
Carlos Magno da Rocha Junior ${ }^{1 *}$; Antônio Gilberto Bertechini2; \\ Alexandre de Oliveira Teixeira ${ }^{3}$; Leonardo Marmo Moreira3; \\ Carla Regina Guimarães Brighenti ${ }^{3}$; Cristina Maria Lima Sá-Fortes ${ }^{4}$; \\ Cleiton Antônio Nunes ${ }^{5}$; Anderson Corassa ${ }^{6}$
}

\section{Highlights}

Oxidative stability in chicken offal oil.

Synthetic antioxidants promote better oxidative stability than natural antioxidants.

Less induction time with natural antioxidants.

Fatty acid profile at different temperatures.

Absence of antioxidant is a mitigating factor for oxidation.

\begin{abstract}
The aim of this study was to examine the use of antioxidants on the oxidative stability of poultry offal oil used in the pet food industry. Five commercial synthetic and two natural antioxidants were used in the following treatments: Control (CON); $\mathrm{CON}+(\mathrm{BHT}+\mathrm{BHA}+\mathrm{ETH} 95) ; \mathrm{CON}+(\mathrm{BHT}+\mathrm{BHA}) ; \mathrm{CON}+(\mathrm{BHA}+\mathrm{PG}+\mathrm{CA}) ; \mathrm{CON}+$ $(\mathrm{BHT}+\mathrm{BHA}+\mathrm{ETH} 70) ; \mathrm{CON}+\mathrm{BHA} ; \mathrm{CON}+(\mathrm{ASC}+$ rosemary); and $\mathrm{CON}+(\mathrm{ASC}+$ tocopherols). Inclusion levels were $0.5 \%$ for the synthetic and $0.625 \%$ for the natural antioxidants. Oxidative stability was determined at

1 PhD Candidate of Postgraduate Program stricto sensu in Animal Science, Federal University of Lavras, UFLA, Lavras, MG, Brazil. E-mail: carlosmagno.rocha@yahoo.com.br

2 Prof. PhD. Department of Animal Science, UFLA, Lavras, MG, Brazil. E-mail: bertechini@ufla.br

${ }^{3}$ Profs. PhDs, Department of Animal Science, Federal University of São João del-Rei, Campus Universitário Tancredo Neves, UFSJ, São João del-Rei, MG, Brazil. E-mail: alexandre_teixeira@ufsj.edu.br; leonardomarmo@gmail.com; carlabrighenti@ufsj.edu.br

${ }^{4}$ Prof. PhD. Department of Animal Science, Federal University of Minas Gerais, Campus Universitário Montes Claros, UFMG, Montes Claros, MG, Brazil. E-mail: crissafortes@ufmg.br

5 Prof. PhD, Department of Food Science, UFLA, Lavras, MG, Brazil. E-mail: cleiton.nunes@ufla.br

${ }^{6}$ Prof. PhD, Department of Animal Science, Federal University of Mato Grosso, Campus Sinop, UFMT, Sinop, MT, Brazil. E-mail: anderson_corassa@ufmt.br

* Author for correspondence
\end{abstract}

Received: Sept. 04, 2020 - Approved: Jan. 28, 2021 
three temperatures $\left(90,110\right.$ and $\left.130^{\circ} \mathrm{C}\right)$. To determine the fatty acid profile, the original sample of the offal oil was considered a negative control. The fatty acids were determined based on the preparation of methyl esters by a transesterification reaction with methanol in alkaline medium, followed by gas chromatography analysis. The different fatty acid types were identified by comparing the retention times of the fatty acid methyl ester standards with the retention times of the observed peaks. Compositional data analysis was carried out. Without the use of antioxidant, induction time is shorter, resulting in lower oxidative stability of the offal oil and consequent loss of its quality due to less time taken to oxidize. The antioxidants used in CON $+(B H T+B H A+E T H 95), C O N+(B H A+P G+C A)$ and $C O N+B H A$ better preserved the essential fatty acids (linolenic and linoleic). Natural antioxidants exhibited higher oxidation, with higher proportions of saturated fatty acids and the worst $\omega 6: \omega 3$ ratios. In conclusion, the synthetic antioxidants used in $\mathrm{CON}+(\mathrm{BHT}+\mathrm{BHA}$ $+\mathrm{ETH} 95), \mathrm{CON}+(\mathrm{BHA}+\mathrm{PG}+\mathrm{CA})$ and $\mathrm{CON}+\mathrm{BHA}$ provided greater protection against oxidation and better preserved the essential fatty acids. The natural antioxidants tested in the present study did not provide satisfactory protection.

Key words: Antioxidants. Extrusion. Pet food. Rosemary. Tocopherols.

\section{Resumo}

Objetivou-se com essa pesquisa avaliar o uso de antioxidantes sobre a estabilidade oxidativa de óleo de vísceras de aves utilizado na indústria pet food. Foram utilizados cinco antioxidantes comerciais sintéticos e dois naturais: Controle (CON); $C O N+(B H T+B H A+E T O 95) ; C O N+(B H T+B H A) ; C O N+(B H A+P G+A C)$; $\mathrm{CON}+(\mathrm{BHT}+\mathrm{BHA}+\mathrm{ETO} 70) ; \mathrm{CON}+\mathrm{BHA} ; \mathrm{CON}+(\mathrm{ASC}+$ alecrim)$; \mathrm{CON}+(\mathrm{ASC}+$ tocoferois $))$. A inclusão dos antioxidantes foi de $0,5 \%$ para os sintéticos e de $0,625 \%$ para os naturais. A determinação da estabilidade oxidativa foi feita em 3 temperaturas $\left(90^{\circ} \mathrm{C}, 110^{\circ} \mathrm{C}\right.$ e $\left.130^{\circ} \mathrm{C}\right)$. Para a determinação do perfil de ácidos graxos, foi considerada a amostra original do óleo de vísceras como controle negativo. A determinação dos ácidos graxos foi baseada na preparação dos ésteres metílicos por reação de transesterificação com metanol em meio alcalino, seguida da análise por cromatografia gasosa. A identificação dos diferentes tipos de ácidos graxos foi obtida comparando os tempos de retenção dos padrões do éster metílico de ácidos graxos com os tempos de retenção dos picos observados. Foi realizada uma análise de dados composicionais. Foi possível observar que, sem utilização de um antioxidante, o tempo de indução é menor, repercutindo em uma menor estabilidade oxidativa do óleo de vísceras, com consequente perda de sua qualidade, devido a um menor tempo gasto para se oxidar. Os antioxidantes utilizados em CON + (BHT+BHA+ETO95), CON $+(B H A+P G+A C)$ e $C O N+B H A$, preservaram mais os ácidos graxos essenciais (linolênico e linoleico). Os antioxidantes naturais tiveram maior oxidação, com maiores proporções de ácidos graxos saturados e as piores relações $\omega 6: \omega 3$. Conclui-se que os antioxidantes sintéticos utilizados em CON + (BHT+BHA+ETO95), $\mathrm{CON}+(\mathrm{BHA}+\mathrm{PG}+\mathrm{AC})$ e $\mathrm{CON}+\mathrm{BHA}$ proporcionaram maior proteção contra a oxidação e preservaram mais os ácidos graxos essenciais. Os antioxidantes naturais, no presente estudo, não apresentaram proteção satisfatória.

Palavras-chave: Alecrim. Antioxidantes. Extrusão. Pet food. Tocoferois. 


\section{Introduction}

The use of additives for pets is becoming increasingly relevant, as the Brazilian pet food market follows trends and innovations of developed countries that, within a humanization concept, meet the needs of owners concerned with the health and wellbeing of their animals. In this way, additives have been intensively used in this sector to provide both nutritional and processing characteristics.

Fat and protein sources are necessary for petfood, and the processing of such sources (e.g. animal meals) can have a deleterious effect and contribute to their oxidation. Reducing temperatures used during their processing and supplying antioxidants can benefit the retention of nutrients in processed foods (Haverkamp, 2020).

In the Brazilian market, natural antioxidants have increasingly replaced synthetic antioxidants to prevent lipid oxidation in pet food, following global trends, especially in the United States and the European Community.

The emphasis on the use of natural antioxidants stems from concerns about the toxicity of some synthetic antioxidants such as BHA (2 or 3-tert-butyl-4-hydroxyanisole, or butylated hydroxyanisole), BHT (2,6-ditert -butyl-4-methylphenol or butylated hydroxytoluene) and ethoxyquin, in addition to a protective relation of natural antioxidants against oxidative damage in the human body (Bonomo, Sanhueza, \& Nieto, 2003). Oxidation is a self-catalytic process that develops with increasing acceleration once it starts. Factors such as temperature, presence of enzymes, incidence of light and concentration of metal ions can influence the formation of free radicals, which are often associated with oxidation reactions (redox reactions) (Araújo, 2015).

One of the most important indicators of the maintenance of oil quality is its oxidative stability (Tan et al., 2017), which is influenced by the fatty acid composition, antioxidant content, presence of other minor compounds (Durmaz \& Gökmen, 2019), excessive drying or overheating (Ribeiro et al., 2019).

The use of oils and fats as a source of energy and palatability in feed for farm animals and pets has become a widespread practice. In the case of the Brazilian market, the animal fat most commonly used is poultry fat or offal oil, whereas soybean oil is the commonly used vegetable oil.

Although the effects of the extrusion process on the nutritional values of feed for farm animals are well documented, literature results regarding the effects of extrusion on dry pet food are often scarce (Monti et al., 2016; Pacheco et al., 2018).

In this context, this study was developed to evaluate the use of synthetic or natural antioxidants on the oxidative stability of poultry offal oil used in the pet food industry.

\section{Material and Methods}

The analyses were performed at the Multi-User Laboratory at the Department of Chemistry (DQ) of the Federal University of Lavras (UFLA).

The oxidative stability of poultry offal oil was evaluated using five commercial synthetic and two natural antioxidants (Table 1), which formed the following treatments: Control $(\mathrm{CON}) ; \mathrm{CON}+(\mathrm{BHT}+\mathrm{BHA}+\mathrm{ETH} 95) ; \mathrm{CON}+$ 
$(\mathrm{BHT}+\mathrm{BHA}) ; \mathrm{CON}+(\mathrm{BHA}+\mathrm{PG}+\mathrm{CA}) ; \mathrm{CON}+$ $(\mathrm{BHT}+\mathrm{BHA}+\mathrm{ETH} 70) ; \mathrm{CON}+\mathrm{BHA} ; \mathrm{CON}+(\mathrm{ASC}$ + rosemary); and CON + (ASC + tocopherols), where $\mathrm{BHT}=$ butylated hydroxytoluene, $\mathrm{BHA}=$ butylated hydroxyanisole, ETH = ethoxyquin,
$P G=$ propyl gallate,$C A=$ citric acid and ASC $=$ ascorbic acid. Antioxidant inclusion levels were $0.5 \%$ for the synthetic and $0.625 \%$ for the natural antioxidants.

Table 1

\section{Composition of the antioxidants used}

\begin{tabular}{|c|c|c|c|c|c|}
\hline \multirow[b]{2}{*}{ Treatment } & \multicolumn{5}{|c|}{ Antioxidants - composition $(\mathrm{g} / \mathrm{kg})^{1}$} \\
\hline & BHT & $\mathrm{BHA}$ & $\begin{array}{l}\text { Ethoxyquin } \\
\text { (ETH) }\end{array}$ & $\begin{array}{l}\text { Propyl gallate } \\
\text { (PG) }\end{array}$ & $\begin{array}{l}\text { Citric acid } \\
\text { (CA) }\end{array}$ \\
\hline T1: CONTROL (CON) & - & - & - & - & - \\
\hline T2: CON + (BHT + BHA + ETH95) & 195 & 15 & 95 & - & - \\
\hline T3: $\mathrm{CON}+(\mathrm{BHT}+\mathrm{BHA})$ & 90 & 90 & - & - & - \\
\hline $\mathrm{T} 4: \mathrm{CON}+(\mathrm{BHA}+\mathrm{PG}+\mathrm{CA})$ & - & 230 & - & 70 & 80 \\
\hline T5: CON + (BHT + BHA + ETH70) & 50 & 5 & 70 & - & - \\
\hline T6: $\mathrm{CON}+\mathrm{BHA}$ & - & 240 & - & - & - \\
\hline T7: CON + (ASC + Rosemary) & \multicolumn{5}{|c|}{ (Acerola + Rosemary): Ascorbic acid (ASC) = $55 \mathrm{~g} / \mathrm{kg}$} \\
\hline T8: CON + (ASC + Tocopherols) & \multicolumn{5}{|c|}{ (Acerola + Tocopherols): ASC $=55 \mathrm{~g} / \mathrm{kg}$} \\
\hline
\end{tabular}

${ }^{1}$ Data obtained from product labels.

Oxidative stability was determined with a Rancimat apparatus (873 Biodiesel Rancimat) at three temperatures $\left(90,110\right.$ and $\left.130{ }^{\circ} \mathrm{C}\right)$, with an air flow of $20 \mathrm{~L} \mathrm{~h}^{-1}$, using $3 \mathrm{~g}$ of sample and $50 \mathrm{~mL}$ of deionized water.

The naturalantioxidants were prepared by diluting the commercial products in offal oil at a 1:20 ratio. The material was stirred for 15 min on a magnetic bar stirrer with heating $\left(50^{\circ} \mathrm{C}\right)$.

To determine the fatty acid profile, the original offal oil sample was considered a negative control and samples from the Rancimat at $130^{\circ} \mathrm{C}$ were collected to detect changes that occurred with the increase in temperature.
Fatty acids were determined based on the preparation of methyl esters by a transesterification reaction with methanol in alkaline medium, followed by gas chromatography analysis (American Oil Chemists' Society [AOCS], 2009), method Ce 2-66. The fatty acid profile is based on the preparation of the methyl esters by a transesterification reaction with methanol in alkaline medium, in which an aliquot of the sample containing approximately $100 \mathrm{mg}$ is converted to methyl esters using a saturated sodium chloride ( $\mathrm{NaCl}$ ) solution and a solution of $2 \mathrm{M}$ potassium hydroxide $(\mathrm{KOH})$ in methanol as esterifying agent.

The fatty acid composition was determined by gas chromatography (GC), 
using a high-resolution gas chromatograph (Shimadzu GC-2010), a capillary column (SP-2330; $30 \mathrm{~mm} \times 0.25 \mathrm{~mm} \times 0.2 \mu \mathrm{m}$ ) and a flame ionization detector. The following chromatographic conditions were employed 1:100 split ratio, initial column temperature of $140{ }^{\circ} \mathrm{C}$ for $5 \mathrm{~min}$ and a ramp from $140^{\circ} \mathrm{C}$ to $250^{\circ} \mathrm{C}$ at a rate of $5^{\circ} \mathrm{C} \mathrm{min}^{-1}$ for $30 \mathrm{~min}$. Helium $(\mathrm{He})$ was used as carrier gas at $1 \mathrm{~mL} \mathrm{~min}^{-1}$ and the detector/injector temperature was set at $260^{\circ} \mathrm{C}$.

The different types of fatty acids were identified by comparing the retention times of the fatty acid methyl ester standards with the retention times of the observed peaks, using "Openchrom" software. The content of each fatty acid was determined as the percentage area of each peak relative to the sum of the areas of all identified peaks.

Table 2

Total induction time (h) at different temperatures

\begin{tabular}{|c|c|c|c|}
\hline \multirow{2}{*}{ Treatment } & \multicolumn{3}{|c|}{ Temperature $\left({ }^{\circ} \mathrm{C}\right)$} \\
\hline & 90 & 110 & 130 \\
\hline T1: CONTROL (CON) & 20.2 & 3.46 & 0.73 \\
\hline T2: $\mathrm{CON}+(\mathrm{BHT}+\mathrm{BHA}+\mathrm{ETH95})$ & 51.17 & 9.37 & 1.7 \\
\hline T3: $\mathrm{CON}+(\mathrm{BHT}+\mathrm{BHA})$ & 34.14 & 6.04 & 1.42 \\
\hline $\mathrm{T} 4: \mathrm{CON}+(\mathrm{BHA}+\mathrm{PG}+\mathrm{CA})$ & 56.3 & 7.92 & 2.25 \\
\hline T5: $\mathrm{CON}+(\mathrm{BHT}+\mathrm{BHA}+\mathrm{ETH70})$ & 51.46 & 7.84 & 1.67 \\
\hline T6: $\mathrm{CON}+\mathrm{BHA}$ & 75.65 & 11.6 & 2.42 \\
\hline T7: CON + (ASC + rosemary) & 17.52 & 3.34 & 0.73 \\
\hline T8: CON + (ASC+ tocopherols) & 20.67 & 3.58 & 0.83 \\
\hline
\end{tabular}

Compositional data analysis was carried out using the "compositions" package of R software (Van den Boogaart \& TolosanaDelgado, 2008).

\section{Results and Discussion}

The evaluation of total oxidation time of the samples at the temperatures of 90, 110 and $130^{\circ} \mathrm{C}$ (Table 2) indicated that the offal oil without antioxidants, or even some samples with antioxidants, had a shorter induction time and, consequently, less oxidative stability (Figure 1). This resulted in loss of quality, due to the shorter time taken for the oxidation process to take place. This process can lead to the generation of unpleasant rancid odors in the oil, which can reduce feed intake, and, most importantly, cause loss of nutritional characteristics, compromising the shelf life and nutritional potential of the product. 

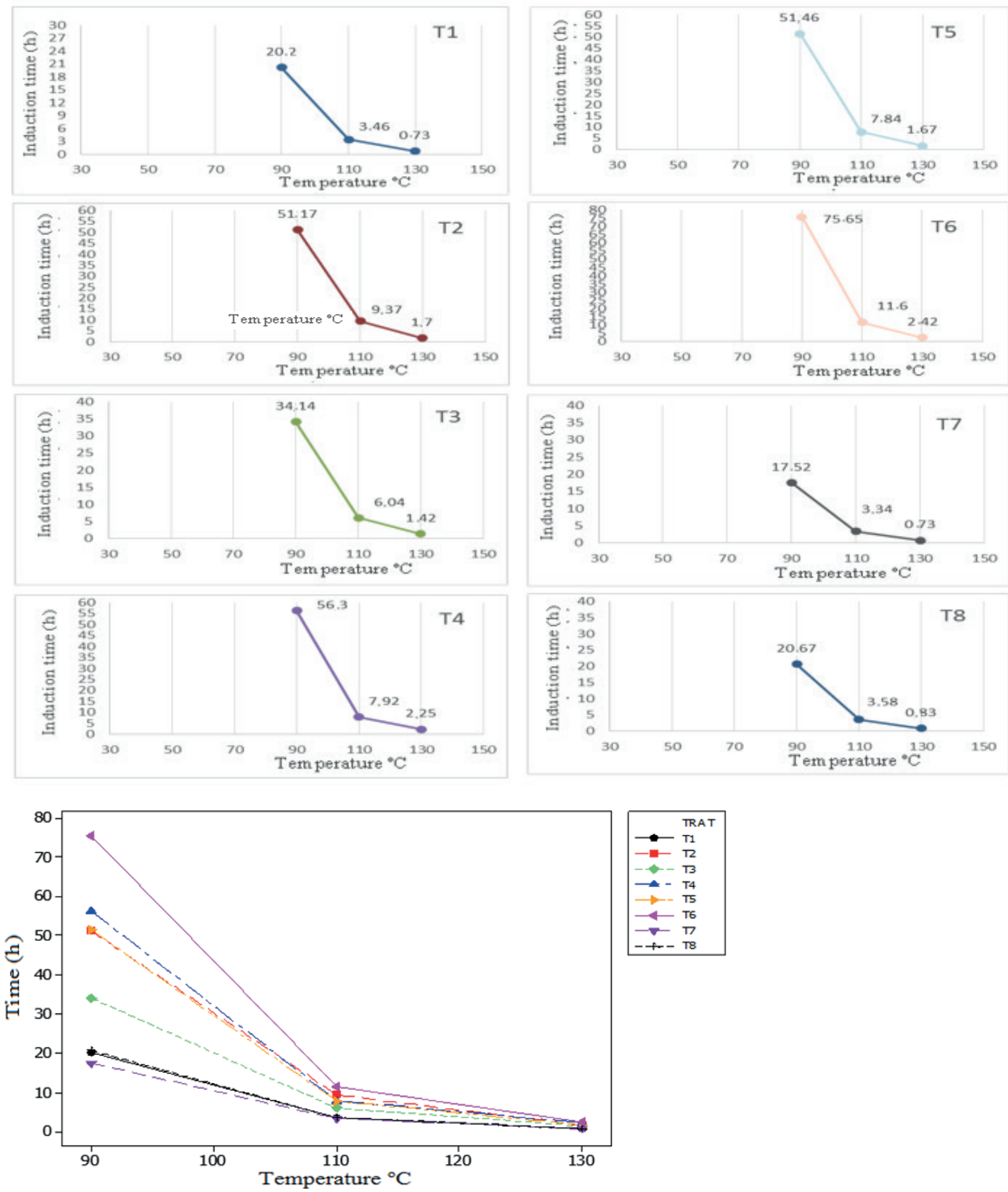

Figure 1. Effect of different temperatures on the induction time of poultry offal oil with different antioxidants. T1: Control (CON); T2: $\mathrm{CON}+(\mathrm{BHT}+\mathrm{BHA}+\mathrm{ETH} 95) ; \mathrm{T3}: \mathrm{CON}+(\mathrm{BHT}+\mathrm{BHA}) ; \mathrm{T} 4: \mathrm{CON}$ + (BHA + PG + CA); T5: CON + (BHT + BHA + ETH70); T6: CON + BHA; T7: CON + (ASC + rosemary); T8: $\mathrm{CON}+(\mathrm{ASC}+$ tocopherols). 
A descriptive analysis of the data (Table 2) revealed, in percentage terms, that all synthetic antioxidants provided an improvement in relation to the control treatment. In the $\mathrm{CON}+\mathrm{BHA}$ treatment, this improvement represented increases of 274 , 235 and $231 \%$ at the temperatures of 90,110 and $130^{\circ} \mathrm{C}$, respectively. This finding indicates that the protection of poultry offal oil using $\mathrm{BHA}$ as the only antioxidant is more efficient than any association of it with other types of antioxidant. This can be seen, for example, in the $\mathrm{CON}+(\mathrm{BHT}+\mathrm{BHA}+\mathrm{ETH} 95), \mathrm{CON}+$ $(\mathrm{BHT}+\mathrm{BHA}+\mathrm{ETH} 70)$ or $\mathrm{CON}+(\mathrm{BHA}+\mathrm{PG}+$ $\mathrm{CA})$ associations, which resulted in shorter induction times.

The natural antioxidants had a less effective or similar behavior in relation to the control treatment. This behavior may have been due to the low inclusion of these antioxidants. In commercial products, some natural antioxidants are included at levels that double or triple the indication of synthetic antioxidants. New investigations of the natural antioxidants used in the present study should be carried out to identify their optimum inclusion levels.

An analysis of the antioxidant activity of hydrolyzed protein from corn gluten meal and distillers dried grains with solubles, prepared with Neutrase (protease from Bacillus amyloliquefaciens, $\geq 0.8 \mathrm{U} \mathrm{g} \mathrm{g}^{-1}$ ) or Alkalase (protease from Bacillus licheniformis, $\geq 2.4 \mathrm{U}$ $\mathrm{g}^{-1}$ ), showed that the protein of corn gluten meal hydrolyzed with Neutrase better prevented lipid oxidation in corn oil and fish oil, in comparison with other antioxidants (Hu et al., 2020). The authors concluded that protein hydrolysates can be used as natural antioxidants in pet food and animal feed, not only inhibiting lipid oxidation, but also potentially improving animal health.

Some studies with rosemary describe an antioxidant efficiency of rosemary extract comparable to or even better than that of the synthetic antioxidants BHT and BHA, besides a synergistic effect with these synthetic antioxidants or with tocopherols (Hernández, García, Jordán, \& Hernández 2014; Miladi et al., 2013). However, in the present study, the antioxidant with rosemary extract was not shown to be a good option, since the induction time was the shortest of all treatments, including control. It is worth mentioning that due to the initial heat treatment to prepare natural antioxidants, the antioxidant properties may have been impaired. Another point to consider is the dosage applied. In the current industrial context, the indication for use of natural antioxidants is at least twice the dose as compared with that of synthetic antioxidants.

The polarity of an antioxidant can influence its antioxidant capacity. In a study carried out with kibbles, hydrophilic antioxidants could be better distributed when added to the premix before extrusion, whereas lipophilic antioxidants could be better distributed when added through the premix or through the coating fat (Ye et al., 2019). The authors deem a shelf-life study necessary to compare the real effect of different ways of adding antioxidants and their impact on food stability.

The antioxidant properties of extracts have received considerable attention in recent years. In the food industry, these effects have been shown to be superior to those of the synthetic antioxidant $\mathrm{BHA}$ and similar to those of BHT. Commercially, they have been used in combination with tocopherols, with 
synergism occurring between rosemary and $\alpha$-tocopherol. Rosemary showed a synergistic effect with citric acid and the antioxidant BHA (Oliveira et al., 2009).

A better response occurred with $\mathrm{CON}+$ (ASC + tocopherols). This may be related to the synergism between vitamins $C$ and $E$, since, to preserve its effectiveness, vitamin $\mathrm{E}$ requires the presence of vitamin $\mathrm{C}$, which would in principle allow the regeneration of vitamin $\mathrm{E}$ itself through the reducing action of vitamin C (Araújo, Rostagno, Albino, Carvalho, \& Birro, 2010).

There was a variation in the concentration of fatty acids in the various treatments, indicating an interference of the temperature with the fatty acid profile of poultry offal oil (Table 3). This variation in fatty acid composition is extremely important for industrial practice, since the change in the percentage of unsaturated fatty acids, especially linoleic and linolenic, impairs the $\omega 6: \omega 3$ ratio, which is stipulated at the time of preparation of formulations for dogs and cats. In the presentstudy, this ratio was more affected in the treatments without the use of antioxidants or with the use of natural antioxidants. If the temperature and type of antioxidant are not taken into account, the $\omega 6: \omega 3$ ratio must be changed. As a consequence, there will be changes the guaranteed levels of the end product, in addition to a lesser beneficial action of polyunsaturated fatty acids in vivo.

Table 3

Fatty acid profile (\%) of poultry offal oil subjected to a temperature of $130^{\circ} \mathrm{C}$ with several antioxidants

\begin{tabular}{|c|c|c|c|c|c|c|c|c|c|}
\hline \multirow{2}{*}{ Fatty acid ${ }^{1}$} & \multicolumn{9}{|c|}{ Treatment $^{2}$} \\
\hline & NC & $\mathrm{TI}$ & T2 & T3 & T4 & T5 & T6 & T7 & T8 \\
\hline Myristic-C14:0 & 0.20 & 0.27 & 0.21 & 0.23 & 0.22 & 0.25 & 0.29 & 0.25 & 0.25 \\
\hline Palmitic - C16:0 & 22.17 & 26.61 & 24.57 & 24.54 & 23.92 & 24.10 & 23.64 & 26.70 & 27.32 \\
\hline Palmitoleic - C16:1 n-7 & 6.60 & 7.13 & 6.84 & 7.45 & 6.78 & 7.33 & 6.90 & 7.02 & 7.09 \\
\hline Stearic - C18:0 & 4.78 & 5.74 & 5.23 & 5.24 & 5.11 & 5.21 & 5.07 & 5.63 & 5.78 \\
\hline Oleic - C18:1(n-9) cis & 44.77 & 48.03 & 46.84 & 48.01 & 46.36 & 47.50 & 45.91 & 47.69 & 48.04 \\
\hline Linoleic - C18:2(n-6) cis & 19.66 & 11.54 & 15.30 & 13.59 & 16.47 & 14.60 & 16.98 & 12.13 & 11.03 \\
\hline y-linolenic - C18:3 n-3 & 1.39 & 0.37 & 0.73 & 0.56 & 0.87 & 0.67 & 0.94 & 0.37 & 0.27 \\
\hline Heneicosanoic - C21:0 & 0.45 & 0.31 & 0.28 & 0.38 & 0.28 & 0.34 & 0.28 & 0.20 & 0.23 \\
\hline Saturated fatty acids & 27.58 & 32.93 & 30.29 & 30.39 & 29.53 & 29.91 & 29.28 & 32.79 & 33.57 \\
\hline Monounsaturated fatty acids & 51.36 & 55.16 & 53.68 & 55.46 & 53.14 & 54.83 & 52.81 & 54.71 & 55.13 \\
\hline Polyunsaturated fatty acids & 21.05 & 11.91 & 16.03 & 14.15 & 17.34 & 15.27 & 17.92 & 12.50 & 11.30 \\
\hline Polyunsaturated/saturated ratio & 0.76 & 0.36 & 0.53 & 0.47 & 0.59 & 0.51 & 0.61 & 0.38 & 0.34 \\
\hline Total unsaturated fatty acids & 72.42 & 67.07 & 69.71 & 69.61 & 70.47 & 70.09 & 70.72 & 67.21 & 66.43 \\
\hline$\omega 6: \omega 3^{3}$ & 14.16 & 30.85 & 21.00 & 24.15 & 18.99 & 21.78 & 18.05 & 33.00 & 41.02 \\
\hline
\end{tabular}

${ }^{1}$ Data obtained based on the percentage area of each fatty acid relative to the total area of the identified fatty acids.

${ }^{2}$ Negative control (NC); T1: Control (CON); T2: CON + (BHT + BHA + ETH95); T3: CON+ (BHT + BHA); T4: CON+ (BHA + PG

+ CA); T5: CON + (BHT + BHA + ETH70); T6: CON + BHA; T7: CON + (ASC + rosemary); T8: CON + (ASC + tocopherols).

${ }^{3} \omega 6: \omega 3:$ Omega 6: Omega 3 fatty acid ratio. 
Together, principal components 1 and 2 represent $87.3 \%$ of the response of the studied variable, with $73.3 \%$ being represented by the first component. In component 1, the variables that contributed positively were oleic and stearic fatty acids, whereas those that contributed negatively were linoleic and $\mathrm{Y}$-linolenic fatty acids (Table 4). This means that the response is inverse; i.e., as oleic and stearic fatty acids increase, linoleic and $\mathrm{y}$-linolenic fatty acids decrease at an average rate of approximately 1:1.

Mammals synthesize fatty acids to palmitic acid (16:0), which can later be elongated to stearic (18:0) and converted to oleic acid (18:1). Unlike mammals, plants and plankton can add extra bonds in oleic acid, forming polyunsaturated fatty acids, such as linoleic acid (18: 2 n6) and alpha-linolenic acid (18:3 n3). In a way, both can be considered essential, since mammals cannot synthesize them and thus they must be included in dog and cat diets (National Research Council [NRC], 2006). Therefore, when including an ingredient with a specific function for animals, variations due to temperature during processing, as well as the use of antioxidants, must be taken into account.

\section{Table 4}

Coefficients of variables relative to each principal component (PC)

\begin{tabular}{|ccc|}
\hline Variable & PC1 & PC2 \\
\hline Eigenvalue & 5.8645 & 1.1202 \\
\hline Proportion of explanation & 0.733 & 0.140 \\
\hline Myristic & 0.231 & 0.085 \\
\hline Palmitic & 0.393 & 0.196 \\
\hline Palmitoleic & 0.272 & -0.675 \\
\hline Stearic & 0.396 & 0.149 \\
\hline Oleic & 0.387 & -0.285 \\
Linoleic & -0.408 & 0.058 \\
Y -linolenic & -0.410 & 0.027 \\
\hline Heneicosanoic & -0.277 & -0.626 \\
\hline
\end{tabular}

The rate of the oxidation reaction depends on the degree of unsaturation in the fattyacidmolecule. Thus, the greater the degree of unsaturation of the oil and/or fat, the greater its susceptibility to oxidation (Araújo, 2015). By analyzing the fatty acid profile of poultry offal oil at room temperature $\left(30^{\circ} \mathrm{C}\right)$ and evaluating the changes in its composition during heating to $130^{\circ} \mathrm{C}$, we observe the transformation that took place, especially in the unsaturations. The lack of antioxidants also appears to a factor mitigating oxidation. The distribution of the treatments with different antioxidants and their relationship with the fatty acids extracted from poultry offal oil is best seen below (Figure 2). 


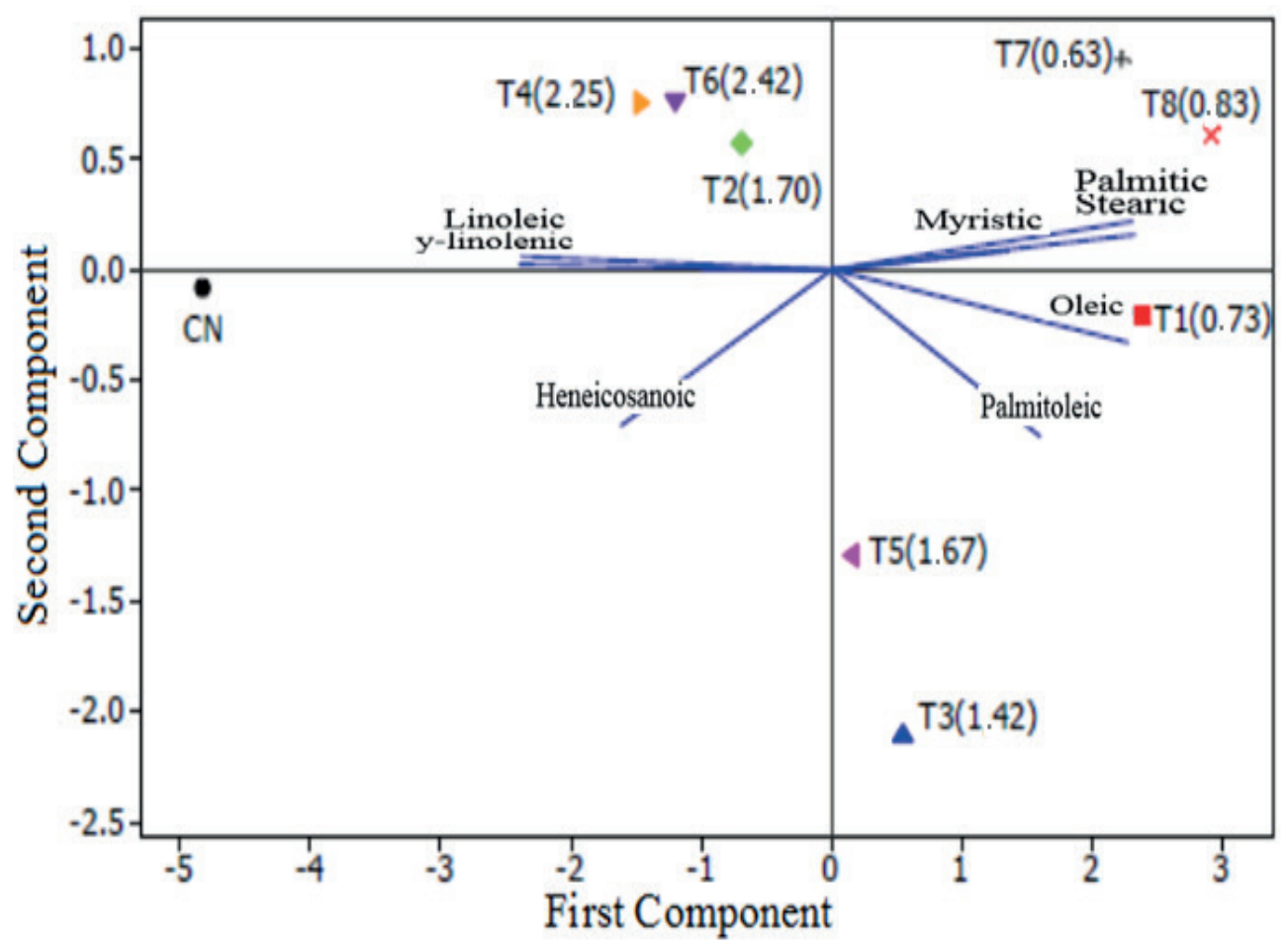

Figure 2. Distribution of fatty acids in the different treatments according to data composition analysis. NC = Negative control; T1: Control (CON); T2: CON + (BHT + BHA + ETH95); T3: CON + $(\mathrm{BHT}+\mathrm{BHA}) ; \mathrm{T} 4: \mathrm{CON}+(\mathrm{BHA}+\mathrm{PG}+\mathrm{CA}) ; \mathrm{T} 5: \mathrm{CON}+(\mathrm{BHT}+\mathrm{BHA}+\mathrm{ETH} 70) ; \mathrm{T} 6: \mathrm{CON}+\mathrm{BHA}$; T7: CON $+($ ASC + rosemary); T8: CON + (ASC + tocopherols).

The $\mathrm{CON}+(\mathrm{BHT}+\mathrm{BHA}+\mathrm{ETH} 95), \mathrm{CON}$ $+(\mathrm{BHA}+\mathrm{PG}+\mathrm{CA})$ and $\mathrm{CON}+\mathrm{BHA}$ treatments better preserved the essential fatty acids (linolenic and linoleic) and are the thus most indicated. On the other hand, the natural antioxidants did not have this response, having undergone greater oxidation. As such, after heating, they had higher proportions of saturated fatty acids and the worst $\omega 6: \omega 3$ ratios. In a study carried out by Racanicci et al. (2004), the main essential fatty acids, linoleic and linolenic, had their concentrations reduced by $29 \%$ and $100 \%$, respectively, in poultry offal oil, once oxidized. Current research has demonstrated the importance of using antioxidants, since, unlike the findings of the aforementioned researchers, despite the reduction in essential fatty acids, linolenic acid was not totally lost.

In this scenario, the composition of oils and fats must be taken into account during formulation so as to ensure better nutritional conditions for these ingredients.

\section{Conclusions}

The use of technological antioxidant additives to protect the poultry offal oil used in pet food against oxidation must be an essential practice. When aiming both at protecting the oil against oxidation and preserving essential fatty 
acids, the most recommended antioxidants are those used in the $\mathrm{CON}+(\mathrm{BHT}+\mathrm{BHA}+$ $\mathrm{ETH95}), \mathrm{CON}+(\mathrm{BHA}+\mathrm{PG}+\mathrm{CA})$ and $\mathrm{CON}$ $+\mathrm{BHA}$ treatments. The natural antioxidants examined in the present study did not provide satisfactory protection.

\section{Conflict of Interest Statement}

The authors declare no conflict of interest.

\section{Acknowledgments}

This study was financially supported by the Coordination for the Improvement of Higher Education Personnel - Brazil (CAPES) - Finance code 001. The authors thank "Planalto Alimentos" for allowing access to their manufacturing facilities and donating the raw materials used in the experiment; the Chemical Analysis and Prospecting Center of the Federal University of Lavras (UFLA); and Finep, Fapemig, CNPq and Capes for providing equipment and technical support for the experiments involving chromatographic analysis.

\section{References}

American Oil Chemists' Society (2009). Preparation of methyl esters of fatty acids. Method Ce 2-66, Seccion C. Official Methods and Recommended Practices of the American Oil Chemists' Society (6th ed.). Urbana, Illinois, USA: AOCS.

Araújo, J. M. A. (2015). Química de alimentos: teoria e prática (6th ed.). Viçosa: Editora UFV.
Araújo, W. A. G., Rostagno, H. S., Albino, L. F. T., Carvalho, T. A., \& Birro, T. (2010). Vitamina E na Nutrição Animal. Nutritime, 7(4), 1292-1303. Retrieved from: https:// www.nutritime.com.br/site/artigo-118vitamina-e-na-nutricao-animal/

Bonomo, A. V., Sanhueza, J., \& Nieto, S. (2003). Natural antioxidants in functional foods: from food safety to health benefits. Grasas y Aceites, 54(3), 295-303. doi: 10.3989/ gya.2003.v54.i3.245.

Durmaz, G., \& Gökmen, V. (2019). Effect of refining on bioactive composition and oxidative stability of hazelnut oil. Food Research International, 116, 586-591. doi: 10.1016/j.foodres.2018.08.077

Haverkamp, M. (2020). Shelf life and quality of minimally processed pet foods and pet food ingredients. Manhattan, Kansas: Kansas State University. Retrieved from https://hdl.handle.net/2097/40632

Hernández, A., García García, B., Jordán, M. J., \& Hernández, M. D. (2014). Natural antioxidants in extruded fish feed: Protection at different storage temperatures. Animal Feed Science and Technology, 195, 112-119. doi: 10.1016/j. anifeedsci.2014.06.003

Hu, R., Dunmire, K. M., Truelock, C. N., Paulk, C. B., Aldrich, G., \& Li, Y. (2020). Antioxidant performances of corn gluten meal and DDGS protein hydrolysates in food, pet food, and feed systems. Journal of Agriculture and Food Research, 2, 100030. doi: 10.1016/j.jafr.2020.100030

Miladi, H., Slama, R. B., Mili, D., Zouari, S., Bakhrouf, A., \& Ammar, E. (2013). Essential oil of Thymus vulgaris $L$. and Rosmarinus officinalis L.: Gas chromatography-mass 
spectrometry analysis, cytotoxicity and antioxidant properties and antibacterial activities ag. Natural Science, 5(6), 729739. doi: $10.4236 / n s .2013 .56090$

Monti, M., Gibson, M., Loureiro, B. A., Sá, F. C., Putarov, T. C., Villaverde, C.,... Carciofi, A. C. (2016). Influence of dietary fiber on macrostructure and processing traits of extruded dog foods. Animal Feed Science and Technology, 220(2016), 93-102. doi: 10.1016/j.anifeedsci.2016.07.009

National Research Council (2006). Nutrient requirements of dogs and cats. Washington, DC: The National Academies Press.

Oliveira, A. C. de, Valentim, I. B., Goulart, M. O. F., Silva, C. A., Bechara, E. J. H., \& Trevisan, M. T. S. (2009). Fontes vegetais naturais de antioxidantes. Química Nova, 32(3), 689702. doi: 10.1590/S0100-404220090003 00013

Pacheco, P. D. G., Putarov, T. C., Baller, M. A., Peres, F. M., Loureiro, B. A., \& Carciofi, A. C. (2018). Thermal energy application on extrusion and nutritional characteristics of dog foods. Animal Feed Science and Technology, 243, 52-63. doi: 10.1016/j. anifeedsci.2018.07.003

Racanicci, A. M. C., Menten, J. F. M., RegitanoD'Arce, M. A. B., Gaiotto, J. B., Longo, F. A., Pedroso, A. A., \& Sorbara, J. O. B. (2004). Oxidação lipídica do óleo de vísceras de aves para redução de seu conteúdo de energia metabolizável para frangos de corte na fase de crescimento. Revista Brasileira de Zootecnia, 33(4), 919-923. doi: 10.1590/S1516-35982004000400012

Ribeiro, L. B., Bankuti, F. I., Silva, M. U. da, Ribeiro, P. M., Silva, J. M., Sato, J.,... Vasconcellos, R. S. (2019). Oxidative stability and nutritional quality of poultry by-product meal: an approach from the raw material to the finished product. Animal Feed Science and Technology, 255(2018), 114226. doi: 10.10 16/j.anifeedsci.2019.114226

Tan, C. H., Ariffin, A. A., Ghazali, H. M., Tan, C. P., Kuntom, A., \& Choo, A. C. Y. (2017). Changes in oxidation indices and minor components of low free fatty acid and freshly extracted crude palm oils under two different storage conditions. Journal of Food Science and Technology, 54(7), 1757-1764. doi: 10.1007/s13197-0172569-9

Van den Boogaart, K. G., \& Tolosana-Delgado, R. (2008). "Compositions": a unified R package to analyze compositional data. Computers \& Geosciences, 34(4), 320338. doi: 10.1016/j.cageo.2006.11.017

Ye, L., Pham-Mondala, A., Li, J., Joseph, P., Nahas, R., \& Michel-Salaun, F. (2019). Using confocal microscopy to estimate the distribution of natural antioxidants in poultry meal and extruded kibbles. European Journal of Lipid Science and Technology, 121(9), 1-7. doi: 10.1002/ejlt. 201800374 